\title{
POPULATIONS OF CEPAEA NEMORALIS FROM SOUTH- WESTERN FRANCE AND NORTHERN SPAIN
}

\author{
PAUL H. HARVEY* \\ Department of Biology, University of York
}

Received 6.xii.70

\section{INTRODUGTION}

Since Cain and Sheppard $(1950,1954)$ demonstrated that visual selection by predators almost certainly influences shell pattern morph frequencies of the polymorphic land snail Cepaea nemoralis around Oxford, several areas have been located where the resulting correspondence with background does not occur. Constant morph frequencies over a large and diverse area despite visual selection has been termed an "area effect". Although it has been argued that random events in the past gave rise to modern-day effects (Goodhart, 1963), repeatable patterns in morph frequencies have been found which cannot be accounted for by the action of visual selection (e.g. Arnold, personal communication; Cameron, 1969; Harvey, 1971a). In these cases the selective forces involved are little understood, and a knowledge of the conditions under which they operate is important to their comprehension.

Guerrucci-Henrion (1966), studying coastal populations in Brittany, produced evidence that changes in rainfall and humidity affect shell colour morph frequencies. Along the westerly-facing coastal dunes in France between Point de Grave and Biarritz there is a rainfall gradient from $800 \mathrm{~mm}$. per year in the north to $1400 \mathrm{~mm}$. in the south (Atlas de France, 1963). With this considerable change in rainfall here, if rainfall affects shell colour morph frequencies in the way suggested by Guerrucci-Henrion, we would expect an increase in pink morph frequency from south to north.

Travelling around the coast from France into Spain, where coastal populations are confined to clifftops, Arnold's (personal communication) and Harvey's (1971a) results predict a decrease in frequency of the fivebanded morph. Arnold found that samples from dunes tend to have a higher fivebanded morph frequency than those from cliffs, while Harvey describes a decrease in fivebanded morph frequency around the coasts of three westerly-facing peninsulas, going from south to north.

Guerrucci-Henrion (1966) also reported an increase in pink shell colour morph frequency with distance from the sea in Brittany, which she interpreted in terms of increasing humidity away from the coast. As well as comparing results from random samples of $C$. nemoralis taken along the French and Spanish coasts, this paper also records the results of an inland transect from the coast in northern Spain to test for morph frequency changes correlated with distance from the sea.

\section{Collegting AND sGoring}

I collected all the samples reported here with the help of my wife, S. E. Tyrrell and M. J. Gray during the summer of 1970.

* Present address: Department of Zoology, University College of Swansea. 
Samples were scored by the methods of Cain and Sheppard (1954) for shell colour and banding, and by the procedure adopted by Arnold (1968) for shell lip colour. Chromosome frequencies have been calculated by an iterative computer program, using the counting method of Cepellini, Siniscalco and Smith (1955).

Details of all the sampling sites, as well as the sample scores, are available elsewhere (Harvey, 1970). Calculated morph and chromosome frequencies are given in Harvey, 1971c.

\section{The coastal tRansect}

(i) Description of the area sampled

The sites sampled are shown in fig. 1. Between Point de Grave and Biarritz the coastline is continuous duneland, except for the Bassin d'Arcachon.

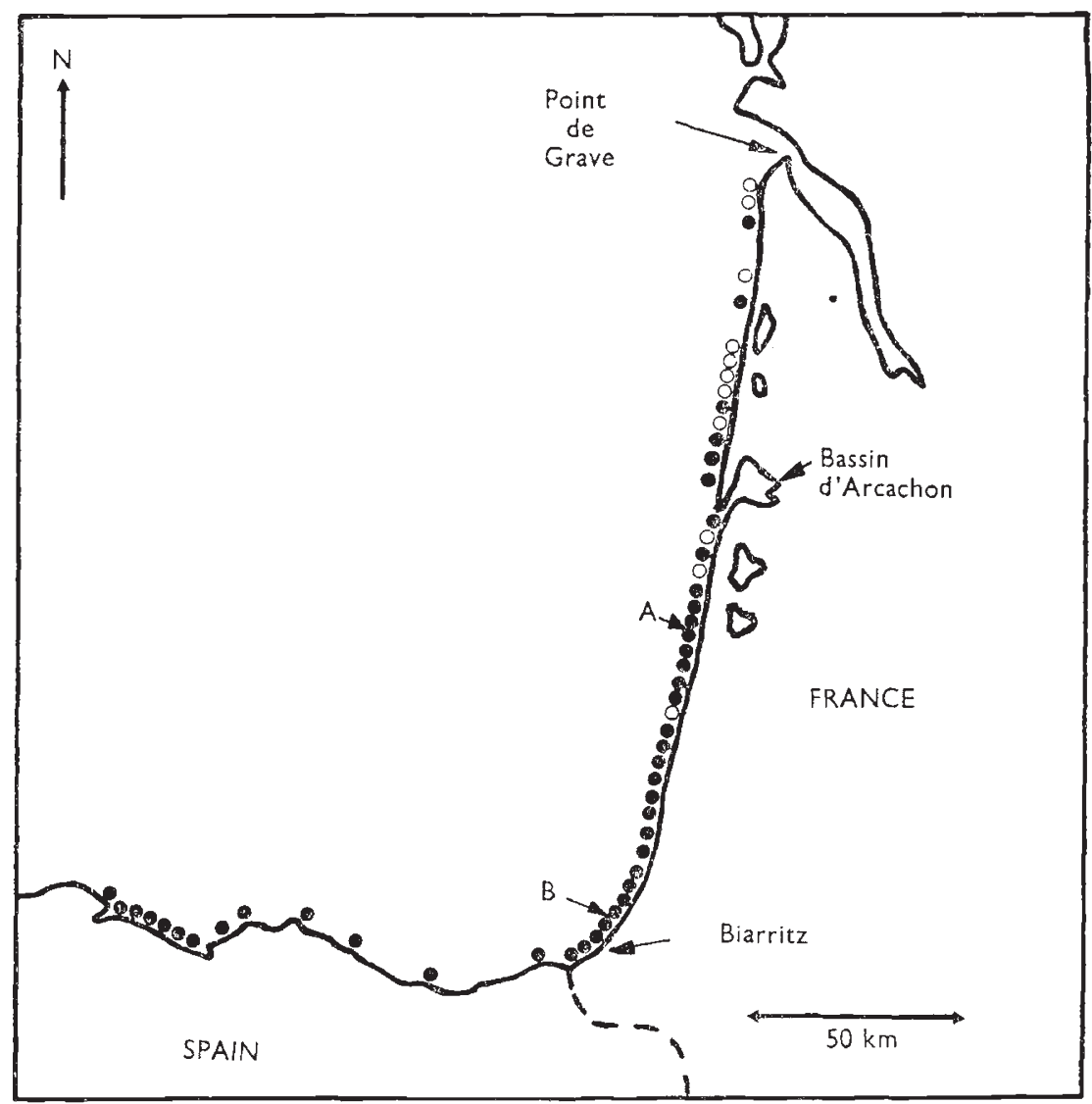

FIG. 1.-Coastal sites searched on the French dunes and Spanish clifftops. Open circles represent sites where $C$. nemoralis was absent. Points $\mathrm{A}$ and $\mathrm{B}$ are cross referrable to fig. 2.

Along these dunes snails are confined to the slacks between the dune tops and the dense pine forests. All the sampes were taken in these slacks, and were mainly predated shells. The vegetation was predominantly marram 
(Ammophila arenaria) with patches of bramble (Rubus spp.), and snails were found associated with the latter.

Sampling sites on the lower cretaceous cliffs west of Biarritz also had bramble as the predominant species with which snails were associated, although here the bramble was thicker and other vegetation more lush, reminiscent of the clifftop vegetation in south Cornwall described elsewhere (Harvey, 1971b).

C. nemoralis was found over the whole area of sampling, but was absent from some sites in the north (fig. 1), where it was also less common when present. The only other large helicid present was Helix aspersa which became less common in the west of Spain, although it was present at all sites searched on the French dunes. Cepaea hortensis and Arianta arbustorum were absent at all sampling sites.

\section{(ii) Results from coastal transect}

(a) Morph frequencies

Morph, gene and chromosome frequencies have been plotted on a cusum graph (fig. 2). The mean frequency of the variable considered is standardised as zero, and each successive point on the graph gives the cumulative sum of deviations from the mean of that sample score and all previous sample scores. This form of plotting data is useful for two reasons: firstly, trends in the data are immediately apparent while individual sample variation is minimised, and secondly, irregular sampling along the coast makes stricter analysis difficult. Changes in frequencies are shown by changes in slope on the graph. Gradients corresponding to mean and extreme frequencies for each variable are given on the graph.

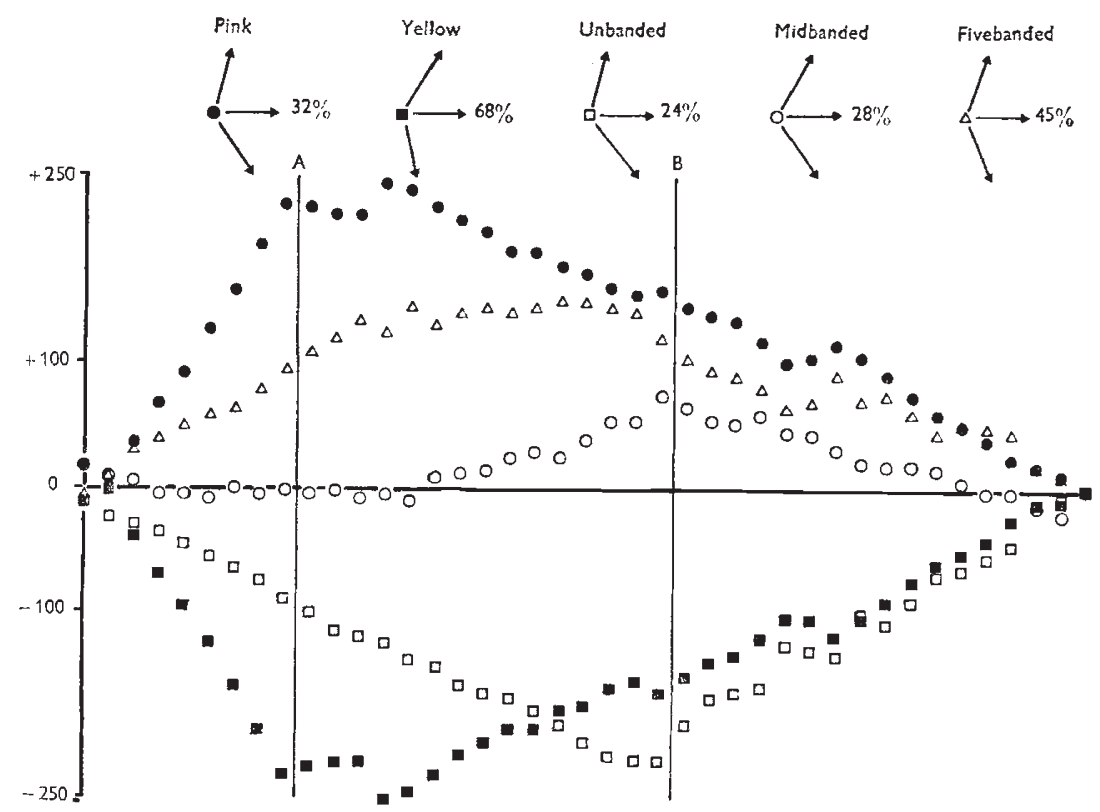

FIG. $2 a$. 

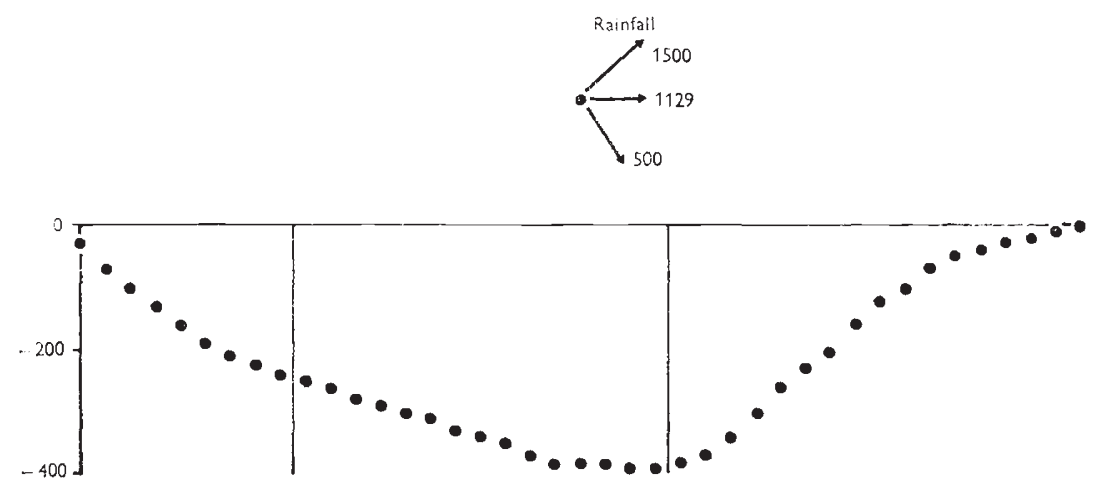

FIG. $2 b$.

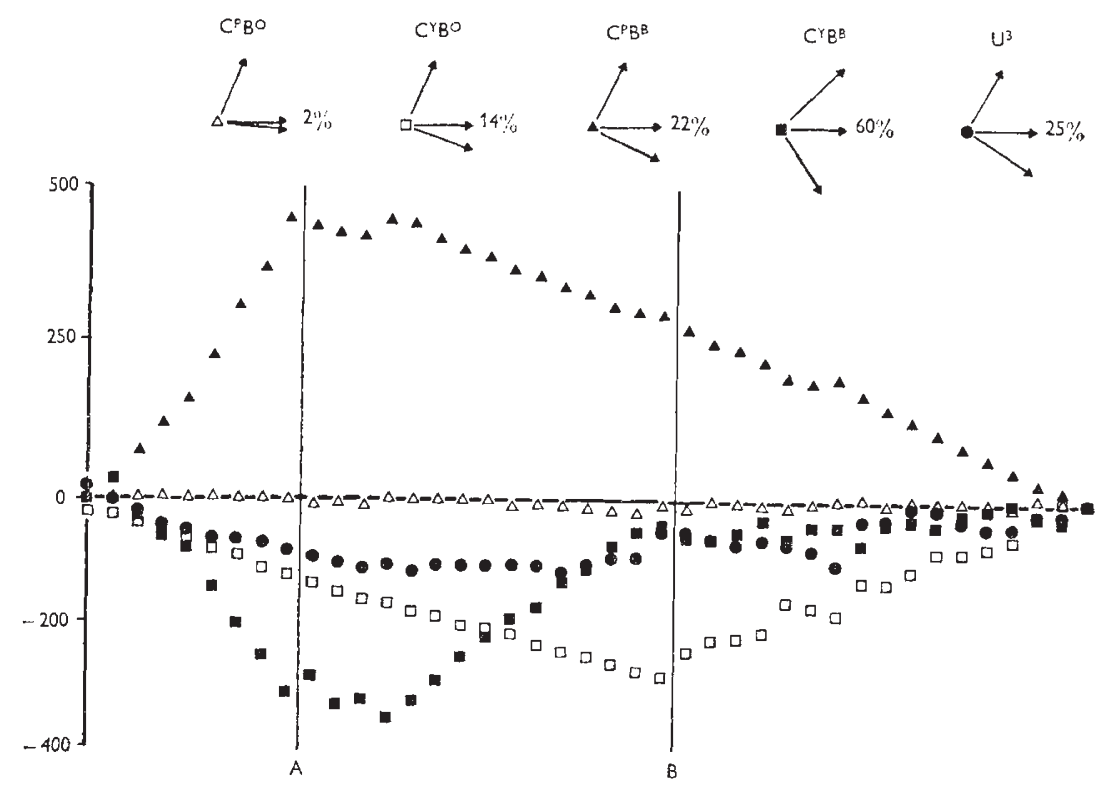

FIG. $2 c$.

F1G. 2.-Cumulative sum plots (see text) of morph, gene and chromosome frequencies with rainfall along the coastline sampled in fig. 1 . Points $A$ and $B$ are cross referrable to fig. 1 .

Shell colour morph frequencies are divided into two areas by point A, which is cross referable between figs. 1 and 2 (Mood's median test for the difference between frequencies north and south of $\mathrm{A}$ is significant at the 5 per cent. level; exact test, $\mathrm{P}=0.012$ ). North of $\mathrm{A}$ pink morph frequency mean is 58 per cent., while south of $A$ it is 25 per cent. In all samples from this coastal transect the brown shell colour morph was absent. There is no evidence for change in shell colour morph frequency as we go from duneland to clifftop and change aspect of the coast at point B (Mood's median test for difference between frequencies south of $A$ and north of $B$, and those west of $\mathrm{B}$ is not significant at the 5 per cent. level; $\left.\chi_{1}^{2}=1 \cdot 4\right)$. 
Fivebanded frequency, as predicted, decreases along the sampling transect, as shown by change in slope of the cusum graph. Unbanded morph frequency which, to an extent, reflects the change in fivebanded frequency shows a distinct change between the last sample taken from dune and the first from clifftop at point B (Mood's median test for the difference between frequencies north and west of $B$ is signicant at the $0 \cdot 1$ per cent. level; $\chi_{1}^{2}$ $=13 \cdot 5$ ). Unbanded morph frequency increases from a mean of 15 per cent.

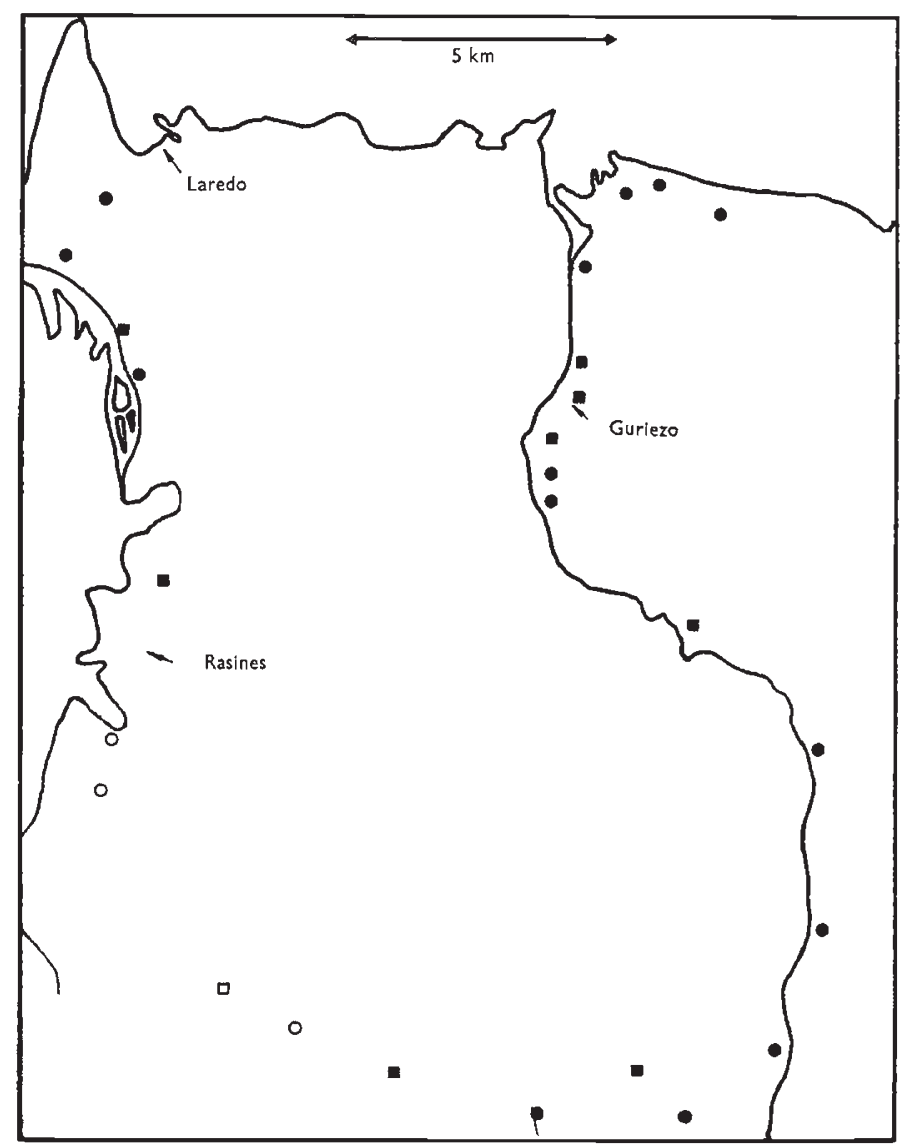

FIG. 3.-The inland transect sampled in northern Spain. Open symbols and squares represent sites where the white lipped and brown morphs were present respectively.

north to 38 per cent. west of B. Midbanded frequency, which on clifftops in Brittany, Cornwall and Pembrokeshire compensates for changes in fivebanded frequency (Harvey, 1971 $a$ ), does not do so in the area studied here. Midbanded frequency is highest in the area between points $A$ and $B$ (mean of 37 per cent.), where both unbanded and fivebanded are below their mean frequencies.

(b) Gene and chromosome frequencies

The notation for the genetics of the polymorphism used here is that agreed by the Second International Conference on Snail Ecology and Genetics, York, 1967, and reported by Cain, Sheppard and King (1968).

z 2 
The repeated demonstrations of linkage disequilibria at the banding (B) and shell colour (C) loci makes the study of chromosome frequencies more informative than gene frequencies alone. The polymorphism at the banding supressor locus $(\mathbf{U})$, not linked to the $B$ and $G$ loci, is treated as a gene frequency.

Increase in the $\mathrm{U}^{3}$ frequency north of $\mathrm{B}$ produces the change in midbanded morph frequency, but west of $B$ it is the increase in $B^{\circ}$ frequency (shown by unbanded morph frequency) that causes the drop in midbanded morph frequency.

The frequency of the double dominant $\mathrm{C}^{\mathrm{P}} \mathrm{B}^{\mathrm{O}}$ chromosome is very low all around the coast, and is only a minor component of chromosome frequency variation.

$\mathrm{C}^{\mathrm{P}} \mathrm{B}^{\mathrm{B}}$ chromosome frequency almost totally dictates the pattern observed in pink morph frequency, dropping from 72 per cent. north of $A$ to 8 per cent. south of $\mathrm{A}$.

$\mathrm{C}^{\mathrm{Y}} \mathrm{B}^{\mathrm{O}}$ chromosome frequency has a similar pattern to unbanded morph frequency, and increases from 2 per cent. on the dunes north of B to 30 per cent. on the cliffs west of $\mathrm{B}$.

The change in yellow morph frequency at $\mathrm{A}$ is determined by $\mathrm{CY}^{\mathrm{Y}} \mathrm{B}^{\mathrm{B}}$ chromosome frequency, although the increase in $\mathrm{C}^{\mathrm{Y}} \mathrm{B}^{\circ}$ frequency west of $\mathrm{B}$ complements the drop in $\mathrm{C}^{\mathrm{Y}} \mathrm{B}^{\mathrm{B}}$ frequency, leaving yellow morph frequency unchanged.

\section{The inland transegt}

\section{(i) Description of the area sampled}

Along the duneland sampled the pine forests cause a barrier to snail populations. On the clifftops snails are more common towards the west, and it is here that an inland transect was sampled. It was possible to sample from a relatively constant vegetational background, over an altitudinal range of about 450 metres, and from the coast up to about $20 \mathrm{~km}$. inland (fig. 3).

The geology of the whole area was lower cretaceous rock, the vegetation at all sampling sites was hedgerow with bramble, and the only other large helicid found was $H$. aspersa. Although samples were taken from near the south-westerly limit of the range of $C$. hortensis, but still within the species range, no $C$. hortensis were found.

\section{(ii) Results from the inland transect}

\section{(a) Morph frequencies}

Morph, gene and chromosome frequencies have again been plotted on a cusum graph (fig. 4).

Going inland from the coast, pink morph frequency increases from less than 10 per cent. to near fixation, and the change is largely reflected by yellow morph frequency. The brown shelled morph, absent along the coastline, was present in several inland samples (fig. 3).

Unbanded morph frequency decreases from about 40 per cent. along the coast, to less than 10 per cent. inland, allowing increases in fivebanded and to a lesser extent midbanded morph frequencies.

The white-lipped morph, not found along the coast, was present in four consecutive inland samples. 

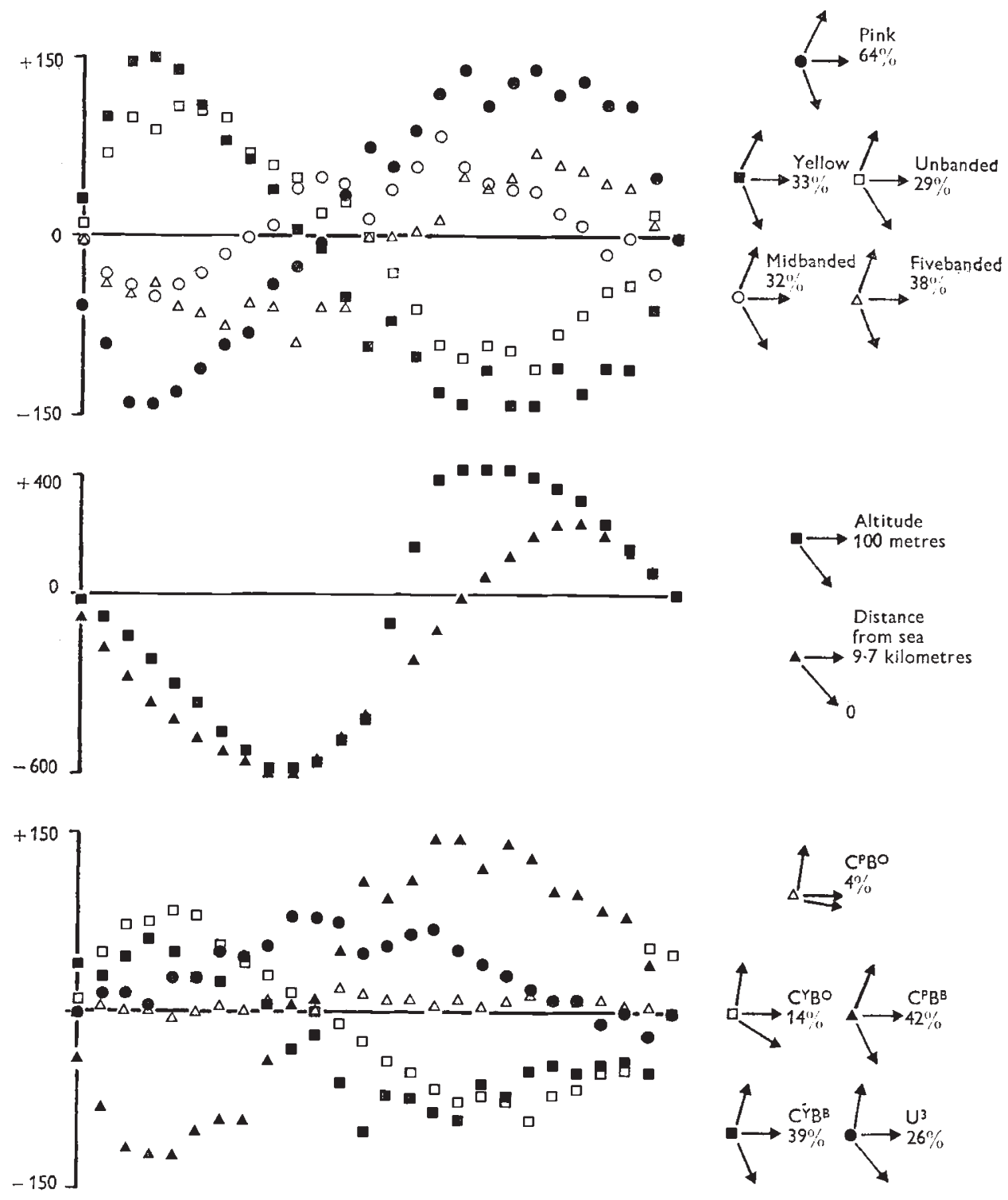

FIG. 4.-Cumulative sum plots (see text) of morph, gene and chromosome frequencies with distance from the sea and altitude of sampling sites for the sites of the inland transect in fig. 3, going from east to west.

\section{(b) Gene and chromosome frequencies}

$\mathrm{U}^{3}$ gene frequency decreases, from east to west, across the sampling area from about 36 per cent. to 18 per cent.

$\mathrm{G}^{\mathrm{P}} \mathrm{B}^{\mathrm{O}}$ frequency is low in all samples and, as along the coast, is only a minor component of chromosome frequency variation.

The increase in both pink and effectively banded morph frequencies inland is caused by an increase in $\mathrm{CPB}^{\mathrm{P}}$ chromosome frequency from less 
than 5 per cent. in coastal samples, to between 60 per cent. and fixation inland. The pattern in $\mathrm{C}^{\mathrm{P}} \mathrm{B}^{\mathrm{B}}$ frequency is reflected by both $\mathrm{C}^{\mathrm{Y}} \mathrm{B}^{\mathrm{O}}$ and $\mathrm{C}^{\mathrm{Y}} \mathrm{B}^{\mathrm{B}}$ chromosome frequencies, which become much lower inland.

In the samples in which brown snails are found the morph is confined to unbanded shells, which is a similar situation to that reported by many workers in Britain (e.g. Cain and Sheppard, 1954; Carter, 1965; Harvey, 1971b). The lip colour locus (P) is dimorphic for albolabiate and pigmented lip in four samples. There is no evidence for linkage disequilibrium between this locus and the banding and shell colour loci, which has been found elsewhere (Cook, 1966; Arnold, 1968). The $\mathrm{P}^{\mathrm{A}}$ allele is found on the four common chromosomes $\left(\mathrm{C}^{\mathrm{P}} \mathrm{B}^{\mathrm{O}}, \mathrm{C}^{\mathrm{P}} \mathrm{B}^{\mathrm{B}}, \mathrm{C}^{\mathrm{Y}} \mathrm{B}^{\mathrm{O}}, \mathrm{C}^{\mathrm{Y}} \mathrm{B}^{\mathrm{B}}\right)$ in the samples considered here.

\section{Discussion}

Sampling from a constant vegetational background across a rainfall gradient $(800-1400 \mathrm{~mm}$.), where annual average relative humidity also increases from 65 per cent. to 75 per cent. (Atlas de France, 1963), does not demonstrate the expected increase in pink shell colour morph frequency, predicted from the results of Guerrucci-Henrion (1966). The results (fig. 2) show that exactly the opposite happens and pink morph frequency decreases from north to south. Point A, where pink morph frequency changes, is not an area where either humidity or rainfall change at all abruptly. It appears that, in this area, morph frequency changes are not dictated by changes in any obvious climatic or vegetational factors. The relatively constant shell colour morph frequencies south and west of $\mathrm{A}$ are maintained despite changes in the frequency of the banding alleles at the closely linked B locus as well as altitude and geology.

Banding morph frequencies, as predicted, change with aspect of the coast, and whether the samples are taken from cliffs rather than dunes. However, although there is a decrease in effectively banded morph frequency, the component of effectively unbanded morph frequency which increases is the unbanded rather than midbanded morph. With both coastal aspect (Harvey, 197la), and duneland versus clifftop (Arnold, personal communication), we expect the component of effectively unbanded that changes in response to fivebanded to be midbanded.

The change in fivebanded frequency is gradual around the coast, agreeing with the hypothesis that coastal aspect influences morph frequency. The change in unbanded morph frequency is abrupt, and along both dunes and clifftops individually it is remarkably constant. Midbanded frequency increases along the dunes, but is low and constant along the clifftops west of Biarritz. Therefore, the cline in frequency of the fivebanded morph around the coast, which corresponds to coastal aspect, is due to changes in midbanded frequency along the dunes and clifftops, as well as a larger change in the frequency of unbanded between dunes and clifftops.

The inland transect demonstrates that pink morph frequency increases with distance from the sea in northern Spain as in Brittany, although in Spain the frequency change is far more extreme and abrupt (94 per cent. change over $5 \mathrm{~km}$. at the east of the transect and 59 per cent. over $4 \mathrm{~km}$. at the west, compared with 50 per cent. over $18 \mathrm{~km}$. in Brittany). Plots of 
distance from the sea and altitude of the sampling site (expressed on a cusum graph in fig. 4), compared with morph frequencies along the inland transect, show clearly that changes in shell colour morph frequencies occur in areas of relatively constant altitude and distance from the sea (between the third and fourth samples from each end of the transect). Therefore, these two variables, although showing a pattern similar to shell colour morph frequencies, cannot themselves be linearly related to morph frequencies. However, the conclusions of Guerrucci-Henrion that conditions of humidity affect shall colour morph frequencies do agree with the findings. Vegetation gets more green and dense quite near the coast, and the fourth samples from both ends of the transect are from appreciably lusher vegetation than the first three.

Guerrucci-Henrion could find no correlation between banding morph frequencies and distance from the sea in Brittany, while in northern Spain unbanded morph frequency drops from about 40 per cent. at the coast to less than 10 per cent. inland. This change is best reflected by change in fivebanded frequency, although to a lesser extent by midbanded. The increase in effectively banded morph frequency compares well with the increase in fivebanded frequency from the "lower" to " intermediate" zones with increase in altitude in the Pyrenees reported by Arnold (1968). The fact that yellow morph frequency is lower at higher altitudes makes interpretation of these results possible in terms of Arnold's conclusions regarding climatic selection. He considered that yellow and unbanded morphs are favoured in areas of lower temperature, while pink and banded morphs are favoured under more temperate conditions. Nevertheless, it is unlikely that the inland samples taken at high altitudes are from areas with more temperate conditions than the coastal samples taken from lower lying land. The selective forces involved, if they are climatic, are not at all obvious.

The increase in pink and effectively banded morph frequencies inland do not correspond with the changes expected if visual selection were over-ridden, either inland or at the coast, by climatic selection. Visual selection, when affecting morph frequencies, causes a positive relationship between pink and effectively unbanded morph frequencies, rather than pink and effectively banded. Samples taken from the background from which the transect was collected would be expected, in terms of visual selection, to be yellow and effectively banded (Cain and Sheppard, 1954).

The brown morph, absent along the coast, was found at several inland sites (fig. 3), and shows no relationship in morph frequency to altitude of sampling site or distance from the sea. The morph was not associated with sites of particularly complex topography in northern Spain, as found by Cain (1968) on British sand-dunes.

The albolabiate morph, associated in Britain with particularly exposed areas (Cook, 1966; Harvey, 1971 b) and in the Pyrenees with high altitudes (Arnold, 1968), is found in the inland transect at four consecutive sites. The sites were the only ones sampled from the bottom of a deep gorge, and were not associated with exposed conditions or high altitude.

It is to be expected that further work, in predicting and testing for the existence of repeated patterns, will eventually give a clearer picture of the forces causing them. 


\section{Summary}

1. Random samples of the land snail Cepaea nemoralis were taken from coastal duneland in south-west France along a rainfall gradient. The coastal clifftops of northern Spain and an inland transect from these cliffs were also sampled.

2. Along the dunes, changes in morph frequency of shell colour observed on a constant vegetational background, do not correspond to changes in rainfall or humidity, as found in Brittany.

3. Effectively banded morph frequency changes in the same way as described by other workers, with both coastal aspect and physical habitat, but the component of effectively unbanded morphs that compensates is unbanded, rather than midbanded as observed elsewhere.

4. In northern Spain, as in Brittany, pink shell colour morph frequency is higher inland than along the coast. In Spain the change in frequency is far more abrupt and extreme than in Brittany, although this could be explained by a selective effect related to environmental humidity differences. In Spain, unlike Brittany, shell banded morph frequency also changes with distance from the sea.

5. Predictable changes in morph frequencies should help to elucidate the selective forces, possibly related to climate, that influence the shell pattern polymorphisms of $C$. nemoralis.

Acknowledgment.-I am grateful to Sue Tyrrell, Michael Gray and my wife for help in collecting the samples, and to Professor Mark Williamson for reading through an earlier copy of the manuscript of this paper.

\section{REFERENCES}

ARnold, R. W. 1968. Climatic selection in Cepaea nemoralis (L.) in the Pyrenees. Phil. Trans. $B, 253,550-593$.

ATlas DE FRANCE. 1963. Paris.

CaIn, A. J. 1968. Sand dune populations of Cepaea nemoralis (L.). Phil. Trans. B, 253, 383396.

CAIn, A. J., AND ShEPPARD, P. M. 1950. Selection in the polymorphic land snail Cepaea nemoralis. Heredity, 4, 275-294.

Cain, A. J., AND Sheppard, P. M. 1954. Natural selection in Cepaea. Genetics, 39, 89-116.

CAIN, A. J., SHEPPARD, P. M., AND KING, J. M. B. 1968. The genetics of some morphs and varieties of Cepaea nemoralis (L.). Phil. Trans. B, 253, 499-517.

CAMERON, R. A. D. 1969. The distribution and variation of three species of land snail near Rickmansworth, Hertfordshire. 7. Linn. Soc. (Zool.), 48, 83-111.

CARTER, M. A. 1965. An investigation of the area effect in Cepaea. D.Phil. Thesis, University of Oxford.

CEPPELlini, R., Siniscalco, M., AND SMITH, C. A. B. 1955. The estimation of gene frequencies in a random mating population. Ann. Hum. Genet., 20, 97-115.

CLARKE, B. C., AND MURRAY, J. J. 1962. Changes of gene frequency in Cepaea nemoralis (L.). Heredity, 17, 445-465.

Cook, L. M. 1966. Notes on two colonies of Cepaea nemoralis (L.) polymorphic for white lip 7. Conch., 26, 125-130.

GUERRUCCI-HENRION, M. A. 1966. Recherches sur les populations naturelles de Cepaea nemoralis (L.) en Bretagne. Arch. Zool. Exptl. Gén., 107, 369-417.

GOODHART, с. B. 1963. Area effects and non adaptive variation between populations of Cepaea (Mollusca). Heredity, 459-471.

HARVEY, P. H. 1970. Some populations of Cepaea nemoralis (L.) in France and Spain. Evolutionary Genetics Research Reports, 6. Filed at the National Lending Library, Boston Spa, Yorkshire. 
harvey, P. H. 1971a. Cepaea nemoralis in Brittany, Cornwall and Pembrokeshire. Heredity, in press.

HARVEY, P. H. 1971b. Cepaea nemoralis on clifftops in south-west England, in preparation. HARVEY, P. H. $1971 \mathrm{c}$. Morph and calculated chromosome frequencies from some populations of Cepaea nemoralis in France and Spain. Evolutionary Genetics Research Reports, 8. Filed at the National Lending Library, Boston Spa, Yorkshire. 